\title{
Determining the Purchase Situation: Cornerstone of Supplier Relationship Management
}

\author{
Evi Hartmann \\ Institute of Technology and Innovation Management \\ Technical University of Berlin \\ Hardenbergstr. 4 - 5, HAD 29, 10623 Berlin \\ Tel: +4969 95630677 \\ Fax: +496995630679 \\ Mobile: +49 1752659514 \\ Email: evi.hartmann@atkearney.com \\ Thomas Ritter \\ Department of International Economics and Management \\ Copenhagen Business School \\ Howitzvej 60 \\ DK - 2000 Frederiksberg, Denmark \\ Tel (direct): +45 38152518 \\ Tel (secretary): +4538152515 \\ Fax: +4538152500 \\ Email: tr.int@cbs.dk \\ Hans Georg Gemuenden \\ Institute of Technology and Innovation Management \\ Technical University of Berlin \\ Hardenbergstr. 4 - 5, HAD 29, 10623 Berlin \\ Tel: +493031426087 \\ Fax: +493031426089 \\ Email: hans.gemuenden@ tim.tu-berlin.de
}

EVI HARTMANN, doctoral student at the Institute of Technology and Innovation Management at the Technical University of Berlin, Germany.

THOMAS RITTER, associate professor at the Department of International Economics and Management, Copenhagen Business School, Denmark.

HANS GEORG GEMUENDEN, professor, chair of the Institute of Technology and Innovation Management at the Technical University of Berlin, Germany.

Competitive Paper submitted to the $17^{\text {th }}$ Annual IMP Conference at the Norwegian School of Management BI, Oslo, Norway, $9^{\text {th }}-11^{\text {th }}$ September 2001 


\begin{abstract}
Purchasing has moved to the agenda of senior management reflecting an increasing strategic attention to benefits that can be gained from management of and cooperation with suppliers. Modern purchasing approaches reflect this changing emphasis towards the importance of quality and innovativeness of suppliers as opposed to pure price negotiations. However, different approaches are suitable for different purchase situations, i.e. for the specific circumstances the buying firm is in. Detailed evaluation and analysis of the purchase situation are even more crucial to a company's sustainable success since new ways of interacting such as electronic marketplaces are developing fast and changing the way firms work together. In this paper, the authors structure different classification models of purchase situations by identifying the underlying dimensions. Based on the literature review the authors have grouped the indicators in four dimensions. Then by combining these dimensions an overall integrated classification model is developed. Finally, suggestions for future research are discussed.
\end{abstract}

\title{
Introduction
}

The field of purchasing has evolved significantly in the last two centuries. The growing pressure of global competition and less internal value-creation has led to the recognition that purchasing is an important contributor to a firm's competitive advantage by both academics and practitioners. An appropriate sourcing strategy can contribute significantly to increase profitability, market share and technological innovation. This increased importance of purchasing relates to different reasons as cost, quality and technology. Because purchase costs account on average for more than $40 \%$ of total expenses they are clearly a major area for potential cost savings (Droege 1998, Arnold 1998). Besides cost benefits purchasing and supply management has a major impact on quality. Companies have tended to concentrate on their core competencies with the aim to increase effectiveness and efficiency (Hamel, Prahalad 1995). The need to nurture core competences has lead to an increased emphasis on outsourcing (Venkatesan 1992). This development reduced a company's internal added value in the product value chain to its core competences and at the same time the supplier's influence on quality increased to a dominant role. A further lever for an increased importance of purchasing is the extremely 
short life cycle of new technology. Companies focus on highly customized supplies instead of purchasing commodities. They hand-over product responsibility and risk to their suppliers to cope with increased product development pressure. Early and extensive supplier involvement shortens the product development process and is an important source of innovation (von Hippel 1988, Bozdogan, Deyst, Hoult, Lucas 1998). The focus of attention has shifted to the significance of co-operative buyer-seller relationships to “enable purchasing to support a firm's strategic positioning" (Harland, Lamming, Cousins 1999, p. 659).

Based on these trends one of the most important objectives of the purchasing function is the development of a supplier network, since a firm's ability to produce a quality product at reasonable cost and in timely manner is mainly influenced by its suppliers' capabilities (Hahn, Watts, Kim 1990). Firms conclude that they will more readily attain long-term cost reduction by forming closer working relationships with "key" suppliers (Harland, Lamming, Cousins 1999). But partnering in general is not the solution for success because of related costs, high resource intensity and risk of dependency. The relationships need to be adapted to the specific purchase situation. Depending on different external contingencies the appropriate relationship type should be developed with different governance structure and relational design. Bensaou (1999) showed that firms "balance a portfolio of different types of relationships rather than rely on one type" which leads to the key question: Which kind of supplier cooperation needs to be established in which purchasing situation to contribute to the success of a company? Or in other words, under which circumstances should a firm try to establish a relationship with its suppliers?

The appropriate analysis of the purchasing situation is even more important since the establishment of electronic marketplaces and web-supported trading (Kaplan, Sawhney 2000), which builds a new dimension for purchasing with reduced interpersonal contact but transactional focus. In a nut shell e-trade offers an even more different approach to do business and as such the decision of how to interact with the supplier base or parts thereof becomes more critical. 
In the literature various dimensions for structuring the purchasing situation have been developed, although an integrated model is missing (Cousins, Spekman 2000, Möller, Förrönen 2000, Dyer, Fröhling 1999, Cho, Chu 1998, Metcalf, Frear 1993, Hubmann, Barth 1990, Müller 1990, Witt 1986, Bogaschewsky, Rollberg 1999, Baumgarten, Wolff 1999, Wildemann 1999, Mittner 1991, Kraljic 1983, Elliott, Glynn 2000, Bensaou, 1999, Cannon, Homburg, Willauer 1998, Olsen, Ellram 1997, Krapfel, Salmond, Spekman 1991, Lamming, Cousins, Notman 1996 etc.). This paper tries to integrate several aspects by building a systematic and consistent framework, which enables managers to identify the appropriate purchasing strategy depending on the situational circumstances.

The paper is organized as follows: Firstly, we provide an overview of the literature on classification and portfolio models of supplier relationships by developing a conceptual framework. Then, based on this literature classification by synthesizing all aspects an integrated classification model is proposed. We close with an outlook of further research opportunities and some managerial implications.

\section{Purchase situation classification dimensions}

In the past portfolio models have been successfully used for assessing more efficiently a company's position in respect to its current position, the projected future and the future desired positions in various dimensions (Wind, Douglas 1981, Ansoff, Leontiades 1976, Markowitz, 1952). The pioneering portfolio theory for management of equity was developed by Markowitz in 1952. In the field of industrial marketing and purchasing recently several portfolios have been developed for evaluating customer and supplier relationships since the early 1980s. The different approaches can be structured by four segmentation dimensions: product, market, supplier and relationship characteristics.

With the term purchase situation we consider all relevant forces and influences related to the acquisition of required materials, services and equipment, which have a potential impact on the way buyer and seller work together. The following four characterization dimensions underline the magnitude of various aspects impacting this sourcing environment. 


\section{Product characteristics}

The most frequently used product characteristic is the purchasing volume (Bogaschewsky, Rollberg 1999, Baumgarten, Wolff 1999, Orths 1999, Wildemann 1999, Baumgarten, Bodelschingh 1996, Mittner 1991, Hubmann, Barth 1990, Müller), which can be measured in three dimensions: monetary spent, number of parts or physical size. The economic volume is analyzed by applying an ABC-analysis, which clusters the spent in three categories (Corsten 1996).

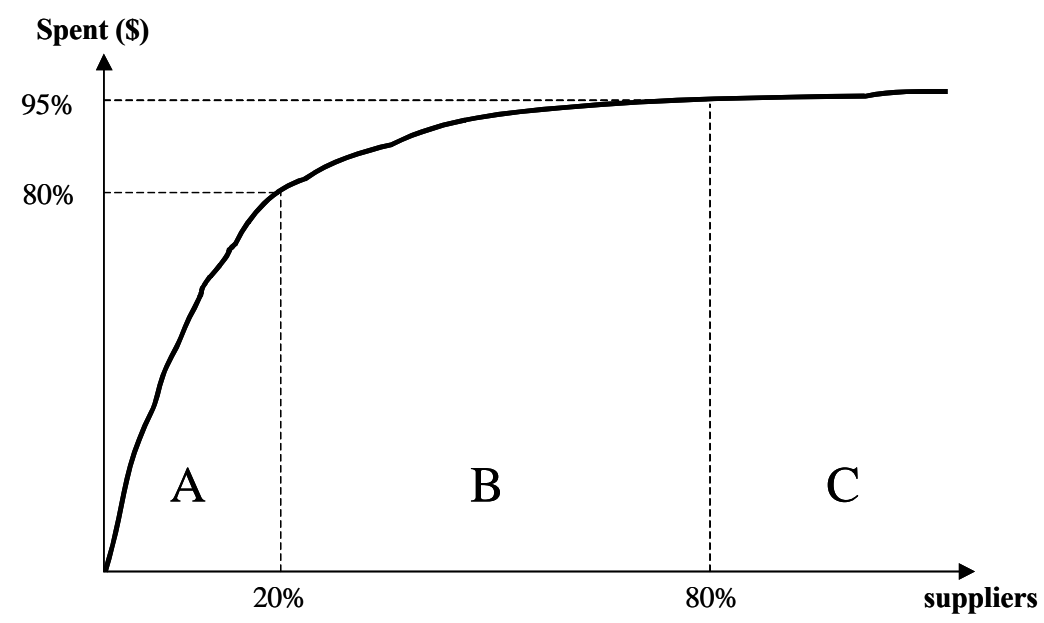

Figure 1: ABC-Analysis in Chemical industry

This classification differs suppliers with significant spent from the mass of suppliers with only small purchase volume (Bogaschewsky, Rollberg, 1999) and clearly demonstrates the economic importance of the supplier (Baumgarten, Wolff, 1999). Especially in the industrial production industry the $\mathrm{ABC}$-analysis is very helpful, since there it is a common situation that the majority of the purchase spent is caused by only few material categories (Corsten 1996). Another volume characteristic is number of parts, which is especially important in discrete production. But besides economic volume and number of parts the physical size can also have an important business impact, especially for products which need large storage space. To reduce inventory carrying cost for large products justin-time order policies could be in place. Therefore some authors not only categorize the 
monetary sourcing spent but also number of parts and physical volume (Bogaschewsky, Rollberg, 1999).

But purchase volume alone can sometimes be misleading. The cheapest component is, in the long run, not necessarily the least expensive. Once the cost of poor quality is factored in the cheapest may well be the most expensive (Burt, 1989). Decisions on sourcing strategies cannot only be based on purchase value or volume, the perceived risk has to be evaluated including its various components as financial risk, performance risk, social risk and other components (Gemünden 1985, p.84,85). Therefore some researchers talk about product and purchase importance (Cannon, Perreault 1999, Homburg 1999, Olsen, Ellram 1997, Homburg 1995, Matthyssens, Van den Bulte 1994, Metcalf, Frear 1993, Kraljic 1983). Olsen and Ellram (1997) detail the importance by economic factors in terms of "dollar value and the impact on the company's profits" (Olsen, Ellram 1997, p. 103), by competence factors, which "describe the extent to which the item purchased is part of the company's core competencies" (Olsen, Ellram 1997, p. 103) and by strategic importance. The closer the purchased product is to the core competencies of the firm, the greater is the strategic importance of the purchased good (Olsen, Ellram 1997). Product importance as "the extent to which a consumer links a product to salient enduring or situation specific goals" (Bloch, Richins 1983, p. 71) is a broader definition for product characteristics. For Metcalf and Frear (1993) the product importance is not an inherent product characteristic, but its perception by the buyer will relate to the "product's ability to satisfy the goals of the buying firm" (Metcalf, Frear 1993, p. 66). Product importance is also influenced by the risk of the supply for the production process, if the delivery is delayed (Mittner 1991, p.22). But not only risk due to delays has to be included in the product importance evaluation, also functional and qualitative aspects relating to product performance, financial factors or social effects have to be further detailed (Gemünden 1985 , p. 90). Product importance also refers to the position of the supply in the value chain of the producing company, which then determines a potential impact of short innovation and product cycle of the supply.

To evaluate the product complexity and standardization another product segmentation dimension is the degree of product customization (Cannon, Homburg, Willauer 1998, Dyer, Cho, Chu 1998, Metcalf, Frear 1993), which can reflect in product specification, 
delivery agreements and specific payment schemes. Ford (1980), Hakansson, Gadde (1992), Wilson (1995) and Metcalf and Frear (1993) talk about "adaptations", which occur when "one party in a relationship alters its processes or the item exchanged to accommodate the other party" (Wilson 1995, p. 339). Adaptations develop over time by implying cost. They can be grouped in different types of adaptation as technical, knowledge-based, administrative, economic and legal (Hakansson, Gadde 1992, 408) and may include customizing products, financial terms, information sharing routines, pricing, inventory stocking policies, delivery schedules and production processes (Cannon, Narayandas 2000, p.412). The product specification dimension is frequently used in the automotive industry, where only limited suppliers deliver highly customized products. They fall in the "keiretsu-category" (Dyer, Cho, Chu 1998, p. 60), with roughly 30 suppliers of more than 300 . Keiretsu suppliers in the automotive industry deliver parts as engine parts, body panels or seats (Dyer, Cho, Chu 1998). The degree of customization underlines the supplier willingness to invest in the relationship. On the other hand it shows the trust and commitment (Morgan, Hunt 1994) of the buying company to rely on a single source.

The demand pattern defines the continuity and age of the relationship (Bogaschewsky, Rollberg 1999, Baumgarten, Wolff 1999, Baumgarten, Bodelschwingh 1996). Suppliers use this measurement as a key indicator for planning the production. As a result of derived demand Fiocca (1982) emphasizes the importance that "industrial marketers must always be up to date about the current and prospective trends" (p. 54).

By reviewing those four sub criteria of product characteristics they are all too important to be excluded. But they need to be weighted depending on their relevance according to the specific circumstance. A balanced scorecard approach can helps to simplify this evaluation process.

\section{Market characteristics}

For classifying a supplier relationship not only the product specific characteristics are important. Many different market aspects influence the purchasing situation, although they may not be fully influenced by both parties of the purchasing process. One frequently used segmentation dimension is the supply risk determined by production 
shortages, product availability, availability of alternatives, which is the "degree to which a buying firm has alternative sources of supply to meet a need" (Cannon, Perreault 1999, p.444), on time delivery, quality acceptance or seasonality (Baumgarten, Wolff 1999, Orths 1999, Wildemann 1999, Baumgarten, Bodelschwingh 1996, Homburg 1995, Hubmann, Barth 1990, Müller 1990, Witt 1986). Wildemann (1999) differentiates between "internal and external supply risk" (p.441). Company external risks are influenced by supply problems with substitutes, seasonality, transport logistics complexity and delivery time, whereas internal risk factors are such as the possibility of indoor production, availability of production know-how and product and production complexity (Wildemann 1999, Lamming et al. 1996).

The second market characteristic besides supply risk is the buying power, each firm must be able to understand its competitive environment (Lamming et al. 1996, p. 176). For defining the buying power, which describes the governance in the purchasing situation, several market indicators have to be summarized - such as industry growth and exit barriers, number of competitors, the number of suppliers and an understanding of the rivalry in the market (Porter 1996, p. 23). Following traditional economic theory when many suppliers compete to sell comparable goods, the market becomes a ready source of information on prices and quality (Cannon, Perreault 1999), which strengthens the position of the buyer. But the opposite occurs if only limited suppliers are in the market, the buying company has to cope with the uncertainty and dependence. The buying power is further described by Geck and Petry (1983) with three characteristics: dominant size of the buying company compared to the supplier, market knowledge advantage of the buyer and the service function of the supplier ("customer is king" (Geck, Petry 1983, p. 17)). The geographic spread is a further sub-criteria of the buying power, which defines the buying company's opportunities concerning global sourcing strategies (Monczka, Trent, Handfield 1998, Kiedaisch 1997). Similar to the buying power definition Cannon, Homburg and Willauer (1998) talk about situational factors as dynamism of price and quality.

The third individual category of market characteristics builds the legal regulation factors. An identification of all legal aspects that affect both the way in which commercial affairs should be conducted and also the way in which organizations should be managed 
(Saunders 1997, p. 60). The present legislation of the countries involved in the purchasing process clearly have to be taken into account in the development of strategies for organizations in general and purchasing and supply management in particular. Specific regulations as company law and laws governing the operation of public sector organizations, commercial and consumer law, health and safety legislation, employment and industrial relations and last but not least law of carriage and transport have to be taken into account if characterizing the supplier market (Saunders 1997, Monczka, Trent, Handfield 1998).

Summarizing the market attributes characterizing the purchasing situation these factors are highly correlated to the product characteristics. As such they need to be integrated in an evaluation model together with the product aspects.

\section{Supplier characteristics}

Supplier characteristics are only used by a few researchers for supplier relationship classification (Elliott, Glynn 2000, Wildemann 1999, Bensaou 1999), whereas many supplier aspects have been evaluated in the literature dealing with the supplier evaluation and selection process (Monczka, Trent, Handfiel 1998, Saunders 1997, van Weele 2000, Koppelmann 1997, Hartmann 1992, Hildebrandt, Koppelmann 2000).

The first group of characteristics is the supplier's resource base by means of revenues, assets, employees, R\&D, production capacity and information (Koppelmann 1997, p. 71). The definition of resources goes along with Hofer, Schendel (1978, p. 145), Helfert (1998, p.51-52), Ritter (1998, p.82-83), who cluster the resource base in four groups: financial resources, physical resources, personnel resources and information resources (p. $82,83)$. In business market the buying company depends in part on these resources of the supplier (Ford et al. 1999, p. 76). Standard performance indicators as in the annual report enable a differentiated judgment for the purchasing management concerning financial stability of the supplier. For a better basis of price negotiation supplier's margins need to be recalculated or at least estimated (Olsen, Ellram 1997). The resource potential describes the suppliers commercial and financial competence, but the technical perspective is as well important (Olsen, Ellram 1997). 
The next dimension characterizes the supplier's competencies including product, process, support functions and management capabilities, which is correlated to the previously mentioned dimension resource base. On the one hand the production process needs to be described concerning specific technology, but also reliability in respect to quality, delivery and punctuality of delivery is included in this segmentation dimension (Koppelmann 1997). An overall strategic fit between buyer and supplier has to be approved. Additionally, characteristics as flexibility, service and communication are integrated in the competence perspective (Hartmann 1992, p. 32). Another main competence characteristic is the innovation competence of the supplier (Lamming, Cousins, Notman 1996), which is a more "longer-term factor" (p.175). Due to expanded emphasis on outsourcing (Venkatesan 1992) the supplier's impact on a buyer's value chain has increased tremendously. Suppliers, who are delivering complete system solutions, have major influence on the buyer's product and process innovativeness. Therefore the supplier's innovation potential can be critical to the buyer's innovation success (Heydebreck 1995, p.115).

A further supplier characteristic is the company network in which the supplier is embedded. The network of further relationships of the supplier can be described by the effect these other relationships may have on the buyer: "neutrality effect, duplication effect, reference effect, prohibition effect, combination effect, deficiency effect, competition effect, access effect, avoidance effect and hierarchy effect (detailed discussion in Ritter 1998, p. 20-22). These criteria evaluate the benefits of the supplier's network for the buying company and influence the buying company's network position.

For evaluating the future potential Wildemann (1999) defines the dimension of supplier development potential by classifying the supplier as "standard" or "key supplier" (p. 442). This development potential of the supplier company has to be determined along the supplier's business processes production, logistics and R\&D. Olsen and Ellram (1997) measure a similar aspect, which they call "relative supplier attractiveness" (p. 106) with respect to future changes. They use factors as "the ability to cope with changes in technology, the types and depth of supplier's current and future technological capabilities, the supplier's current and future capacity utilization, supplier's speed in development, ability to cope with changes in the environments" (Olsen, Ellram 1997, p. 
111). In this dimension the learning potential is also integrated, which the supplier offers to the buying company. These factors make a company choose a specific supplier. Some of the factors making a supplier attractive are also used in a supplier selection situation. The last supplier dimension is the supplier value, which summarizes the various reasons why a buyer should work together with a certain supplier. Along with Walter et al. (2000), who analyze the value functions from a supplier perspective, the value functions are differentiated in direct (profit, volume and safeguard function) and indirect ones (innovation development, market-, scout- and access function). Direct value functions as purchase cost savings, large purchase volume and safeguard suppliers, who deliver even if it may be a relatively unfavorable deal, directly contribute to the buyer's profitability independent from further supplier relationships. Indirect value functions as joint innovation development with the supplier, development of further sources due to the reference of a supplier or information gathering due to the supplier's scout function in the market capture connected effects in the future or in further supplier relationships (Walter et al. 2000). The fulfillment of these various value functions determines the buyer value of a certain supplier relationship.

\section{Relationship characteristics}

In the past decade relationship characteristics supporting the success of relationships have been in focus of the relationship marketing research (Dyer, Chu 2000, Ryssel, Ritter, Gemünden 2000, Walter, Müller, Helfert 2000, Joshi, Stump 1999, Doney, Cannon, Mullen 1998, Doney, Cannon 1997, Smeltzer 1997, Norris, McNeilly 1995, Morgan, Hunt 1994, Dwyer, Schurr, Oh 1987).

Basis of any form of cooperation is trust. Smeltzer (1997) describes a trustworthy supplier with the following attributes: "does not act in a purely self-serving manner, accurately discloses relevant information when requested, does not change supply specifications, standards or costs to take advantage of the other parties and generally acts according to normally accepted ethical standards" (p. 42). Another definition of trust is "confidence or predictability in one's expectations about another's behavior, and confidence in another's goodwill" (Dyer, Chu 2000, p.260). Morgan and Hunt (1994) conceptualize trust as existing when one party has confidence in an exchange partner's 
reliability and integrity (p.23). Trust occurs for Smeltzer (1997) because of corporate identity, image and reputation. On the one hand a set of perceptions or personal constructs about the own company are important (corporate identity), on the other hand the outside view of the company (corporate image) are levers for trust. Additionally "supplier reputation" (Doney, Cannon 1997, p. 37) describes the actual attributes outsiders ascribe to the company. This describes the extent to which "firms and people in the industry believe a supplier is honest and concerned about its customers" (Doney, Cannon 1997, p. 37). Smeltzer is linking trust with corporate identity, image and reputation as follows: "Identity equals the extent to which we believe we can be trusted. Image equals the extent to which we believe others think we can be trusted. Reputation equals the extent to which others actually trust us" (p. 44). Butler (1991) identifies ten conditions of trust: "availability, competence, consistency, discreetness, fairness, integrity, loyalty, openness, promise fulfillment and receptivity" (p. 648). Trust in supplier relationships is an important source of competitive advantage, since it "lowers transaction costs, facilitates investments in relation-specific assets and leads to superior information sharing routines" (Dyer, Chu 2000, p. 259). Especially for specific sourcing approaches as "open book negotiations" where the supplier is required to "open its books" and expose secret, sensitive information to the customer (Lamming et al. 2000) a trustful relationship is the required basis for taking that explicit risk of information transparency. A trustworthy party is "known to reliably make good faith efforts to behave in accordance with prior commitments, makes adjustments in ways perceived as fair by the exchange partner and does not take excessive advantage of an exchange partner even when the opportunity is available" (Dyer, Chu 2000, p. 260). Trust in supplier relationship includes a certain degree of optimism that vulnerable know-how will not be exploited or transferred to third parties without prior consent (Gemünden 1999 p.242). Helfert (1998) is defining this optimism more specific with perceived honesty, perceived benevolence and perceived competence (p. 14). The degree of trust can be measured by social embeddedness, institutionalized processes or routines for fairly and reliably dealing and alignment of economic incentives between the business partners. "Social relations, rather than institutional arrangement or generalized morality are mainly responsible for the production of trust in economic life" (Granovetter, 1985, p. 491). 
The second important lever for successful relationships is commitment. Commitment is defined along with Walter, Müller and Helfert (2000) as "a kind of lasting intention to build and maintain a long-term relationship" (p.4). They differentiate between three types of commitment: affective commitment by means of the positive attitude towards the future existence of the relationship, instrumental commitment whenever some form of investment (time or other resources) is made and temporal commitment indicating the timely component of the relationship. These three types characterize in detail "the exchange partner believing that an ongoing relationship with another is so important as to warrant maximum efforts at maintaining it" (Morgan, Hunt 1994, p.23). Bensaou (1999) refers to the instrumental dimension by analyzing the buyer's and supplier's willingness for specific investments.

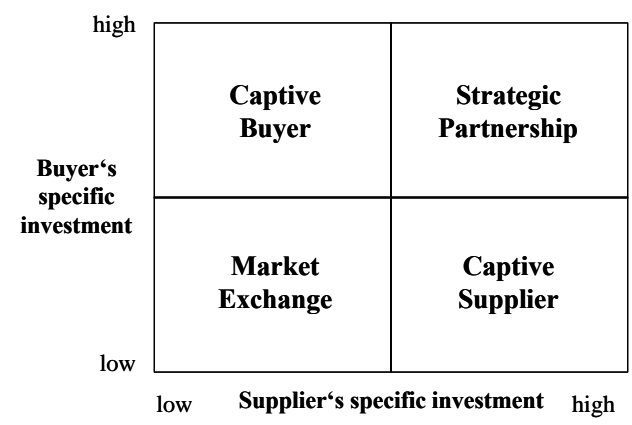

Figure 5: Types of relationship (Bensaou 1999)

High commitment reduces the possibility to break a supplier relationship and increases the tendency to adapt to organizational and environmental changes (Gemünden 1999, p.243). Due to high commitment the willingness is intense to accept common norms, procedures and interfaces.

This high level of commitment creates stability or continuity, which is another segmentation dimension of relationships (Dyer, Chu 2000). Dyer and Chu refer to the automotive industry, where continuity is extremely important due the regular model change and the need for a supplier to re-win the business. Continuity cannot only be expressed by re-winning the business after a model change, but also by the overall length of the relationship (Doney, Cannon 1997) Most researchers have proved a strong 
correlation between the length of a relationship and trust, since trust develops and builds over time.

Gadde and Snehota (2000) define the fourth dimension of relationships involvement by three characteristics: "coordination of activities, adaptations of resources and interaction among individuals". The activities carried out by the supplier and buyer can be more or less tightly coordinated, more or less specifically adapted to the requirements of the counterpart and the interactions can be more or less intense. Gadde and Snehota (2000) underline that close interaction among supplier and buyer make their choices more interdependent and affect both commitment and trust in the relationship, which in turn impacts on coordination and adaptations.

The fifth factor characterizing a relationship is satisfaction. Satisfaction can be defined as "the degree to which the business transaction meets the business performance expectations of the partners" (Wilson 1995, 337). Wilson (1995) specifies satisfaction with the addition performance satisfaction, which includes both product-specific performance and non-product attributes. The level of performance satisfaction in the relationship is determined by the resources committed to the partnership and by the degree of commitment of the parties involved. For Gruen (2000) satisfaction is "the member's assessment of the relative value of the basic exchanges in the relationship" (p. 369). The primary linkage between satisfaction and suppliers and buyers behaviors is generally considered to be loyalty, which is a sub-dimension of commitment (Helfert 1998, p. 15). Satisfaction is likely to have some impact on retention and co-production. A relationship will not endure if the supplier is unable to meet the buyers expectations, then the buyer will seek alternative partners (Wilson, Jantrania 1996).

A sixth relationship characteristic is the existence of relationship promotors (Walter 1998). Since all previously mentioned dimensions are subjective and dependent on personal judgment a relationship promotor has the important role to manage the interaction between supplier and buyer so that trust, commitment, satisfaction, involvement and continuity can be build. The relationship promotor influences the stability effect of these characteristics, which guarantee a successful supplier relationship (Stoelze 2000, p.11). He acts as an intermediator between supplier and buyer, who 
supports information exchange, identification and meeting of key players, coordination of activities and realization of negotiation results (Walter 1998, p. 126).

Reviewing the relationship characteristics emphasizes the correlation and interdependence of all characteristic groups. These dependencies are also stressed by the analysis approach of Elliot and Glynn (2000) who have chosen the dimension of loyalty which is kind of combination of trust, commitment, involvement and satisfaction. Little satisfaction has negative impact on the degree of trust, which then has an impact on commitment (Walter, Müller, Helfert 2000) and also describes the degree of involvement. Therefore those six factor groups need to be integrated within one dimension to be able to judge about the weakness or strength of the relationship and its easiness or problematic appearance. This overall construct is also called relationship quality by several authors.

\section{Purchase Situation Classification Models}

In the following table the contributions of various authors are displayed. None of the 25 researchers has covered all four dimensions and only three researchers have at least covered three. 15 out of 25 classification models have included two dimensions, whereas the product characteristics have been used in nearly all segmentation portfolios.

\begin{tabular}{|c|c|c|c|c|}
\hline Researcher & Product characteristics & $\begin{array}{c}\text { Market } \\
\text { characteristics }\end{array}$ & $\begin{array}{c}\text { Supplier } \\
\text { characteristics }\end{array}$ & $\begin{array}{c}\text { Relationship } \\
\text { characteristics }\end{array}$ \\
\hline $\begin{array}{l}\text { Baumgarten, } \\
\text { Bodelschwingh } \\
1996\end{array}$ & $\begin{array}{l}\text {-Purchase value } \\
\text {-Demand pattern }\end{array}$ & -Delivery risk & & \\
\hline $\begin{array}{l}\text { Baumgarten, } \\
\text { Wolff } 1999\end{array}$ & $\begin{array}{l}\text {-Purchase value } \\
\text {-Demand pattern }\end{array}$ & -Delivery risk & & \\
\hline Bensaou 1999 & $\begin{array}{l}\text {-Buyer's specific } \\
\text { investment }\end{array}$ & $\begin{array}{l}\text {-Supplier's } \\
\text { specific } \\
\text { investment }\end{array}$ & & \\
\hline $\begin{array}{l}\text { Bogaschewsky, } \\
\text { Rollberg } 1999\end{array}$ & $\begin{array}{l}\text {-Purchase volume } \\
\text {-Purchase value } \\
\text {-Demand forecast } \\
\text { accuracy }\end{array}$ & & & \\
\hline $\begin{array}{l}\text { Campbell, } \\
\text { Cunningham } 1982\end{array}$ & $\begin{array}{l}\text {-Product technology } \\
\text {-Production process }\end{array}$ & $\begin{array}{l}\text {-Competitor } \\
\text { analysis (\# } \\
\text { buyers, \# } \\
\text { suppliers, growth } \\
\text { rate, market } \\
\text { share) }\end{array}$ & & $\begin{array}{l}\text {-Life cycle of } \\
\text { relationship }\end{array}$ \\
\hline $\begin{array}{l}\text { Cannon, } \\
\text { Homburg, } \\
\text { Willauer } 1998\end{array}$ & -Product features & $\begin{array}{l}\text {-Situational } \\
\text { factors }\end{array}$ & & $\begin{array}{l}\text {-Relationship } \\
\text { factors }\end{array}$ \\
\hline
\end{tabular}




\begin{tabular}{|c|c|c|c|c|}
\hline $\begin{array}{l}\text { Cannon, Perreault } \\
1999\end{array}$ & -Product importance & $\begin{array}{l}\text {-Availability of } \\
\text { alternatives } \\
\text {-Supply market } \\
\text { dynamism }\end{array}$ & & \\
\hline $\begin{array}{l}\text { Dubinsky, Ingram } \\
1984\end{array}$ & $\begin{array}{l}\text {-Profit contribution } \\
\text { (present and potential) }\end{array}$ & & & \\
\hline $\begin{array}{l}\text { Dyer, Cho, Chu } \\
1998\end{array}$ & $\begin{array}{l}\text {-Degree of product } \\
\text { customization }\end{array}$ & & & \\
\hline $\begin{array}{l}\text { Elliott, Glynn } \\
2000\end{array}$ & -Buyer loyalty & & $\begin{array}{l}\text {-Relationship } \\
\text { value to supplier }\end{array}$ & \\
\hline Fiocca 1982 & $\begin{array}{l}\text {-Sales concentration } \\
\text {-Derived demand }\end{array}$ & $\begin{array}{l}\text {-Structure of the } \\
\text { power in the } \\
\text { market }\end{array}$ & & $\begin{array}{l}\text {-Buying } \\
\text { process } \\
\text { complexity }\end{array}$ \\
\hline Homburg 1995 & $\begin{array}{l}\text {-Economic importance of } \\
\text { purchase }\end{array}$ & $\begin{array}{l}\text {-Complexity of } \\
\text { supply situation }\end{array}$ & & \\
\hline Homburg 1999 & $\begin{array}{l}\text { - Economic importance of } \\
\text { supply }\end{array}$ & $\begin{array}{l}\text {-Complexity of } \\
\text { supplier situation }\end{array}$ & & \\
\hline $\begin{array}{l}\text { Hubmann, Barth } \\
1990\end{array}$ & $\begin{array}{l}\text {-Buying company } \\
\text { dimension (e.g. purchase } \\
\text { value) }\end{array}$ & $\begin{array}{l}\text {-Supplier market } \\
\text { (e.g. Risk) }\end{array}$ & & \\
\hline Kraljic 1983 & $\begin{array}{l}\text {-Strategic importance of } \\
\text { purchasing }\end{array}$ & $\begin{array}{l}\text {-Complexity of } \\
\text { supply market }\end{array}$ & & \\
\hline $\begin{array}{l}\text { Krapfel, Salmond, } \\
\text { Spekman } 1991\end{array}$ & & & & $\begin{array}{l}\text {-Relationship } \\
\text { value } \\
\text {-Interest } \\
\text { commonality }\end{array}$ \\
\hline $\begin{array}{l}\text { Lamming, } \\
\text { Cousins, Notman } \\
1996\end{array}$ & $\begin{array}{l}\text {-Type of commodity, part } \\
\text { or service }\end{array}$ & $\begin{array}{l}\text {-Functional and } \\
\text { organizational } \\
\text { structure }\end{array}$ & & \\
\hline $\begin{array}{l}\text { Matthyssens, Van } \\
\text { den Bulte } 1994\end{array}$ & $\begin{array}{l}\text {-Complexity of purchasing } \\
\text { needs and requirements }\end{array}$ & $\begin{array}{l}\text {-Complexity of } \\
\text { supply market }\end{array}$ & & \\
\hline $\begin{array}{l}\text { Metcalf, Frear } \\
1993\end{array}$ & $\begin{array}{l}\text {-Degree of } \\
\text { standardization/complexity } \\
\text {-Importance of purchase } \\
\text {-Novelty/frequency of } \\
\text { transaction } \\
\text {-Importance of product }\end{array}$ & & & \\
\hline Mittner 1991 & -Purchase value & -Supplier market & & \\
\hline Müller 1990 & $\begin{array}{l}\text {-Purchase value } \\
\text {-Technical complexity }\end{array}$ & -Delivery risk & & \\
\hline $\begin{array}{l}\text { Olsen, Ellram } \\
1997\end{array}$ & & $\begin{array}{l}\text {-Relative } \\
\text { supplier } \\
\text { attractiveness }\end{array}$ & & $\begin{array}{l}\text {-Strength of } \\
\text { current } \\
\text { supplier } \\
\text { relationship }\end{array}$ \\
\hline Orths 1999 & -Purchase value & -Delivery risk & & \\
\hline Wildemann 1999 & -Purchase value & -Delivery risk & $\begin{array}{l}\text {-Supplier power } \\
\text {-Supplier } \\
\text { development } \\
\text { potential }\end{array}$ & \\
\hline Witt 1986 & $\begin{array}{l}\text {-Cost of purchase } \\
\text {-R\&D potential of buyer }\end{array}$ & $\begin{array}{l}\text {-Competitive } \\
\text { advantages on } \\
\text { supplier market } \\
\text {-Technology } \\
\text { development } \\
\text {-Supply risk }\end{array}$ & & \\
\hline
\end{tabular}


Figure 6: Overview literature review on supplier relationship classification

\section{Combination of major dimensions}

After the literature review of various different dimensions for characterizing a purchasing situation the most frequently used portfolio models are discussed.

Most researcher combine product characteristics with market factors (Homburg 1999, 1995, Matthyssens, Van den Bulte 1994, Heege 1987). The standard variable for the product perspective is purchase dollar volume, disregarding if number parts or storage capacity are more expressive. To characterize the market situation often the supply risk is selected.

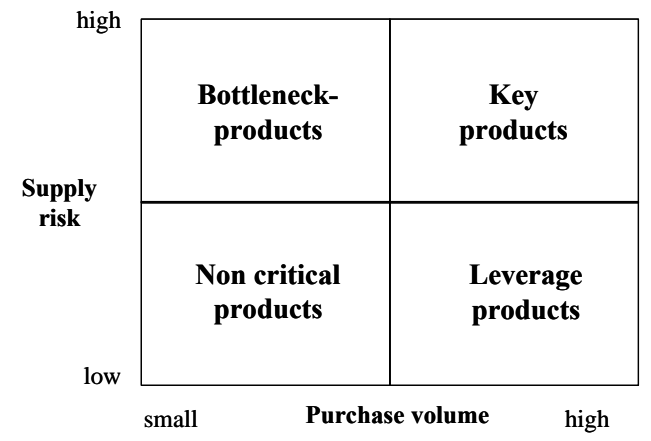

Figure 2: Supplier classification (Heege 1987)

Referring to Turnbull, Zoljiewski (1995), who discusses the classification matrix of Shapiro who evaluates customers from a supplier's perspective (1987, p.104) and Krapfel et al. (1991) who also classifies customers from a supplier's perspective, four relationship types can be built: partner, friend, rival and acquaintance. But these classification models focus only on the supplier's perspective and therefore only incorporate aspects, which are relevant for the supplier e.g. cost to serve a customer, net price realized by the customer. Other researchers as Olsen and Ellram (1997) and Wildemann (1999) have used a sequenced approach for defining the purchasing situation characteristics. Wildemann even combined three dimensions: product, market, supplier perspective. 

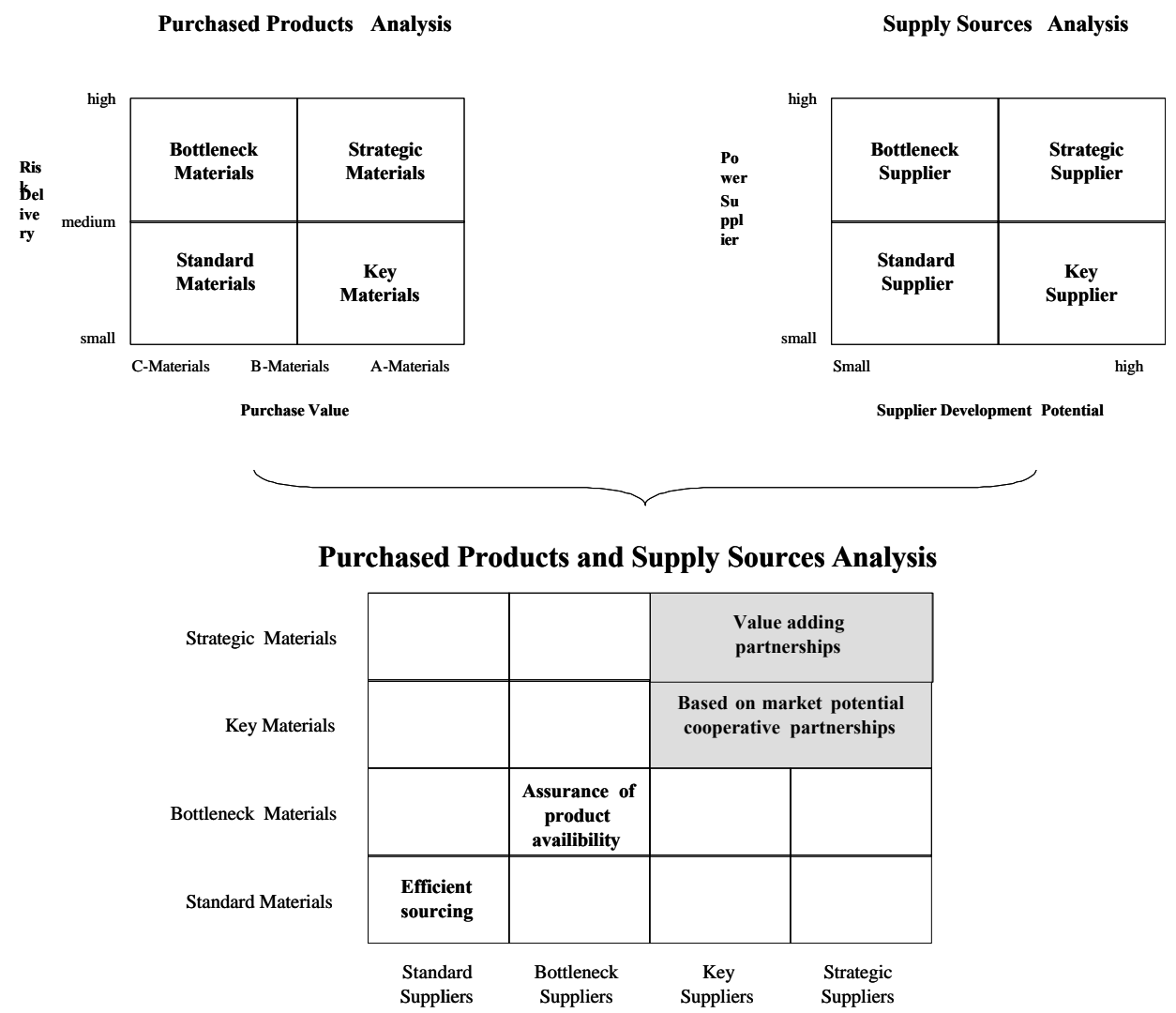

Figure 3: 2-step approach for purchasing situation analysis (Wildemann 1999)

Various portfolios only focus on the relationship characteristics and combine several relationship factors for a very detailed understanding of the purchasing situation in respect to the relationship (Elliott, Glynn 2000, Bensaou 1999).

\section{Relationship fit}

The authors see the need to combine all four characteristic types discussed above within one classification model by simultaneously minimizing the interdependence between the different dimensions. Such an approach offers a meaningful tool for both academics and practitioners. We have to stress that due to the specific situational circumstances a contingency approach is recommended to be able to adapt the importance and weight of the various factors. The buyer business impact dimension summarizes product characteristics (purchase volume [monetary, units and physical space] and the degree of 
customization) and all supplier characteristics (supplier resource base, competence, network and value) by relating their importance to the buying company's business impact. The supplier market competitiveness dimension is an accumulation of supply risk, buying power and legal regulations. The third dimension, the relationship attractiveness refers to relationship characteristics as trust, commitment, continuity, involvement, satisfaction and existence of relationship promotors.

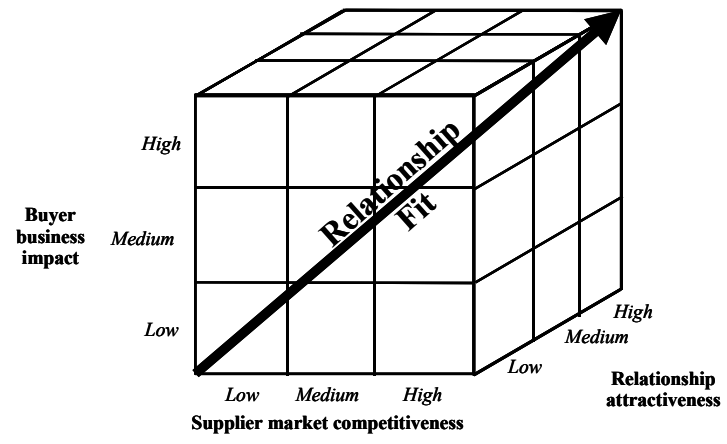

Figure 4: Relationship fit

An important item characterizing the dimension of the buyer business impact is the purchase volume (Bogaschewsky, Rollberg 1999, Baumgarten, Wolff 1999, Orths 1999, Wildemann 1999, Baumgarten, Bodelschingh 1996, Mittner 1991, Hubmann, Barth 1990, Müller 1990). If measured by monetary spent, number of parts or physical size has to be decided individually depending on the product. The second item chosen by the authors for characterizing the buyer business impact is the degree of product customization. Highly customized products have a higher business impact for the buyer, since the buyer is dependent on the one specific supplier concerning product performance (Morgan, Hunt 1994) and shifting cost are very high. The third major lever determining the buyer business impact is the supplier resource base (Koppelmann 1997, p.71). The resource potential describes the supplier's commercial and financial competence (Olsen, Ellram 1997). Related to the commercial and financial competence are supplier's competences including product, process, support functions, management capabilities and innovation competence, so that supplier's competences build the fourth item for the buyer business impact dimension. Besides the different areas of competences the supplier's network is 
an important driver for the business impact. Depending on potential business partners out of the supplier's network further benefits can be defined. The last chosen item is the value function of a supplier relationship, which summarizes all relevant benefits and advantages due to close interaction with a certain supplier. With increasing extent of these six items grows the importance of the buyer business impact. High buyer business impact leads to the hypothesis that a high extent of relationship, or in other words, a more relational approach is necessary to guarantee any kind of success.

Detailing the supplier market competitiveness dimension, the authors have used all three items mentioned in the literature as market characteristics: supply risk, buying power and legal regulation. Most important is the supply risk, which is the "degree to which a buying firm has alternative sources of supply to meet a need" (Cannon, Perreault 1999, p.44). Additionally more general market factors as industry growth rate, exit barriers and number of buyers and suppliers have also to be included in the evaluation of the supplier market competitiveness. And the third supplier market competitiveness item is the legal regulation, which determines all legal aspects and restrictions. The extent of those three items characterizes the strength of the supplier market competitiveness, which has an indirect impact on the need of relationships. Low or no supplier market competitiveness (i.e. limited competent supplier base) supports the necessity of relationships to successfully handle the purchase situation.

The third dimension is the relationship attractiveness. The authors have chosen all six items - trust, commitment, continuity, involvement, satisfaction and relationship promotor - which have been commonly discussed in literature to define the extent of relationship attractiveness. Although those items are not completely independent and have some overlaps they are necessary to cover all different aspects, which are influencing relationship attractiveness. High extensity of those items leads to high relationship attractiveness, which supports the establishment of successful relationships. Only the appropriate fit of these three dimensions guarantees a long-term relationship success. Low business impact, high supplier market competitiveness, but high relationship attractiveness predict poor or no relationship success since the benefits of the supplier relationship are only limited due to the business environment. In purchase situations with high business impact, limited supplier market competitiveness, but only 
low relationship attractiveness only poor relationship success can be expected based on a reduced level of trust, commitment, satisfaction, continuity, involvement or missing relationship promoters. On the other hand in a procurement environment with high business impact, limited supplier market competitiveness and high relationship attractiveness the probability of relationship success is very high.

The authors have aggregated the in literature described four dimension into three which are independent from each other and have a linear correlation to the necessity of relationships, whereas the four dimensions discussed in the literature are not independent and show some overlap. For example are supplier characteristics not independent from product and purchase importance for the buyer. On the other hand are product and purchase importance high, if the purchase volume is high. Demand pattern is especially important, if purchase volume is high. Supplier competencies determine further supplier development potential. These examples show arguments, why the authors have only three dimensions, which seem to have the major impact on differentiating a purchase situation. With a special emphasis on the increased complexity of the purchasing function due to the internet these three dimensions seem especially important. Diverse solutions of electronic business (e.g. electronic marketplaces) enforce the need to be able to define a target purchasing strategy, since the internet opened new opportunities to the purchasing situation.

\section{Managerial impact and further research}

For sustainable purchasing management it is very important to have a deep understanding of the purchase situation, i.e. sourcing environment. Based on the above detailed dimensions the purchase situation can be classified. This classification is then the cornerstone for establishing an appropriate purchase management, appropriate in the meaning of suitable to the purchasing situation. Depending on the situation, suppliers can be targeted and links to the suppliers can be built. We deliberately use the word link here because it will not always be a relationship, which needs to be built. Finally, the sourcing strategy can be implemented keeping in mind that the implementation depends on other actors as well as on the firm's own abilities. 


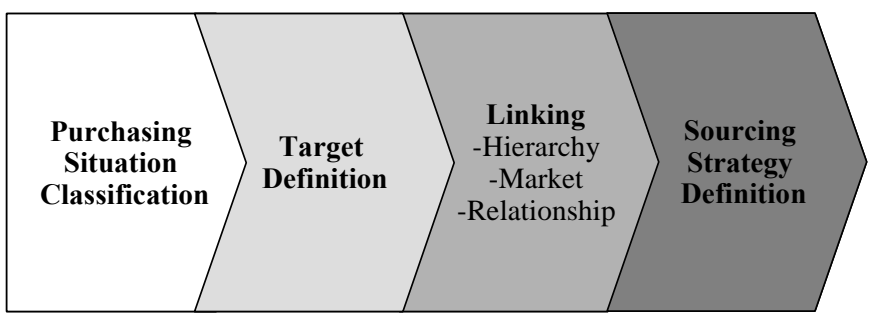

Figure 5: 4-step approach for a consistent purchasing management

This systematic approach before taking strategic sourcing decisions has to be analyzed especially with respect to new trends of electronic commerce, which have created different ways in doing business. The impact of new types of doing business via electronic marketplaces has to be reflected upon in the analysis. Changes in the purchase situation due to the globalization trend based on the management of knowledge-related barriers to entry and economies of scale, which is extremely facilitated through the internet, have to be incorporated (Harland, Lamming, Cousins 1999). Further analysis has to focus on shifts from global offerings and sourcing strategies to local needs with culturally specific goods and services. Effects of electronic commerce concerning information sharing, information transparency, but also concerning the opposite effect, the "opaqueness of information" (Lamming et al. 2000, pp. 5) needs to be detailed. How does the internet impact the existing purchase situation? Or maybe even more challenging what kind of new answers does the internet offer to the described decisions?

But in order to use the proposed model further research efforts need to investigate the operationalization of the purchasing situations. As shown above, there are many indicators for each dimension. It is reasonable to assume that the importance of different variables varies between relationships and between industries. As such it will be challenging to find any general rule according to which information can be summarized in a way so that different situations can be compared and contrasted.

Furthermore, as shown the definition of the purchasing situation is only the first step. The construct "purchase situation" needs to be set into context, meaning to discuss potential impacts. We have argued that the fit of a relational strategy increases along the three 
dimensions. However this needs to be tested. In particular we are interested if certain purchase situations favor the introduction of e-commerce. As we have seen in the recent past, there has been a lot of enthusiasm with B2B platforms but also a lot of drawbacks. We would argue that - besides other factors - platforms have been introduced where the purchase situation was not suitable. This could be taken as a starting point for further investigations into this area.

Additional research has to be investigated in analyzing interdependencies between the purchase situation and effects of purchase strategy implementation. Furthermore defining the purchase strategy is not a static process, all circumstances leading to a certain purchase situation have to be reviewed within a regular time frame. The argumentation leading to a specific purchase strategy has to be regularly proofed if still appropriate to the given circumstances. Especially nowadays with extremely fast development of new technologies the review aspect is very important. As such another further research field would be the dynamics of change in purchase situations and their causes.

Overall, our definition of purchase strategy provides us with a solid starting point for further analysis into relationship management in supply networks. This starting point character comes on top of the fact that our model can be used as an analytical tool for managerial decision making.

\section{References}

Ansoff, H. I., Leontiades, J. (1976): Strategic Portfolio Management, in: Journal of Management, No. 4

Arnold, U. (1998): Einkaufskooperationen in der Industrie, in: Arnold, U.: Erfolg durch Einkaufskooperationen, Gabler, Wiesbaden, p. 13-56

Arnold, U. (1998): Grundlagen von Einkaufskooperationen, in: Arnold, U.: Erfolg durch Einkaufskooperationen, Gabler, Wiesbaden, 1-12

Arnold, U. (1998): Marktlich integrierte Kooperationen: Netzwerke und Allianzen in Beschaffung und Absatz, in: Gassert, H., Prechtl, M., Zahn, E.: Innovative Dienstleistungspartnerschaften. Neue Formen der Zusammenarbeit zwischen Industrie und Dienstleistern, Schäffer Poeschel, Stuttgart, p. 56-91

Baumgarten, H., von Bodelschwingh, K. (1996): Kostenreduzierung durch gestraffte Abläufe, in: Beschaffung aktuell, 2, p. 35-38

Baumgarten, H., Wolff, S. (1999): Versorgungsmanagement - Erfolge durch Integration von Beschaffung und Logistik, in: Hahn, D., Kaufmann, L.: Handbuch Industrielles Beschaffungsmanagement, Gabler, Wiesbaden, p. 321-342 
Bellmann, K. (1999): Produktion und Beschaffung - Management einer innerbetrieblichen Schnittstelle, in: Hahn, D., Kaufmann, L.: Handbuch Industrielles Beschaffungsmanagement, Gabler, Wiesbaden, p. 277-294

Bensaou, M. (1999): Portfolios of Buyer-Supplier Relationships, in: Sloan Management Review, Summer, p. 35-44

Bloch, P. H., Richins, M. L. (1983): A Theoretical Model for the Study of Product Importance Perceptions, in: Journal of Marketing, 47, p. 69-81

Bogaschewsky, R., Rollberg, R. (1999): Produktionssynchrone Zulieferungskonzepte, in: Hahn, D., Kaufmann, L.: Handbuch Industrielles Beschaffungsmanagement, Gabler, Wiesbaden, p. 231-250

Bozdogan, K., Deyst, J., Hoult, D., Lucas, M. (1998): Architectural innovation in product development through early supplier integration, in: R\&D Management, 28 (3), p. $163-173$

Brege, E.-M. (1998): Meeting Purchasing Strategies in the Corrugated Board Industry, $14^{\text {th }}$ IMP Conference, Turku

Burt, D. N. (1989): Managing Suppliers Up to Speed, in: Harvard Business Review, JulyAugust, p. 127-135

Butler, J. K. Jr. (1991): Toward Understanding and Measuring Conditions of Trust: Evolution of a Conditions of Trust Inventory, in: Journal of Marketing, 17 (3), 643663

Campbell, N. C. G., Cunningham, M. T. (1982): Customer Analysis for Strategy Development in Industrial Markets, in: Strategic Management Journal, Vol. 4, p. 369380

Cannon, J. P., Homburg, C., Willauer, B. (1998): International Supplier Relationships and Organizational Learning, $14^{\text {th }}$ IMP Conference, Turku

Cannon, J. P., Narayandas, N. (2000): Relationship Marketing and Key Account Management, in: Sheth, J. N., Parvatiyar, A. (2000): Handbook of Relationship Marketing, Sage Publications, Thousand Oaks, 407-429

Cannon, J. P., Perreault, W. D. Jr. (1999): Buyer-Seller Relationships in Business Markets, in: Journal of Marketing Research, Vol. 36 (11), p. 439-460

Corsten, H. (1996): Beschaffung, p. 682, in: Corsten, H., Reiß, M.: Betriebswirtschaftslehre, München, p. 609-736

Cousins, P. D., Spekman, R. (2000): Strategic Supply and the Management of Inter and Intra Organizational Relationships, $16^{\text {th }}$ IMP Conference, Bath

Cunningham, M. H., Varadarajan, P .R. (1995): Strategic Alliances: A Synthesis of Conceptual Foundations, in: Journal of the Academy of Marketing Science, 23 (4), 282-296

Doney, P. M., Cannon, J. P. (1997): An Examination of the Nature of Trust in BuyerSeller Relationships, in: Journal of Marketing, Vol. 61 (4), p. 35-51 
Doney, P. M., Cannon, J. P., Mullen, M. R. (1998): Understanding the Influence of National Culture on the Development of Trust, in: Academy of Management Review, Vol. 23 (3), p. 601-620

Droege, W. P. J. (1998): Gewinne einkaufen, Gabler, Wiesbaden

Dubinsky, A. J., Ingram T. N. (1984): A Portfolio Approach to Account Profitability, in: Industrial Marketing Management, Vol. 13, p. 33-41

Dyer, J. H., Cho, D. S., Chu, W. (1998): Strategic Supplier Segmentation: The Next "Best Practice" in Supply Chain Management, in: California Management Review, 40 (2), p. $57-77$

Dyer, J. H., Chu, W. (2000): The Determinants of Trust in Supplier-Automaker Relationships in the US, Japan and Korea, in: Journal of International Business Studies, Vol. 31 (2), p. 259

Elliott, G., Glynn, W. (2000): Segmenting Industrial Buyers by Loyalty and Value, $16^{\text {th }}$ IMP Conference, Bath

Fiocca, R. (1982): Account Portfolio Analysis for Strategy Development, in: Industrial Marketing Management, Vol. 11, p. 53-62

Ford, D. (1980): The Development of Buyer-Seller Relationships in Industrial Markets, in: European Journal of Marketing, 14 (5/6), 339-354

Ford, D., Gadde, L.-E., Hakansson, H., Lundgren, A., Snehota, I., Turnbull, P., Wilson, D. (1999): Managing Business Relationships, John Wiley \& Sons, Chichester

Freiling, J. (1995): Die Abhängigkeit der Zulieferer. Ein strategisches Problem, Gabler, Wiesbaden

Fröhling, O. (1999): Portfolios für die Beschaffung, in: Hahn, D., Kaufmann, L.: Handbuch Industrielles Beschaffungsmanagement, Gabler, Wiesbaden, p. 475-488

Gadde, L.-E., Snehota, I. (2000): Making the Most of Supplier Relationships, in: Industrial Marketing Management, 29 (4)

Geck, H. M., Petry, G. (1983): Nachfragermacht gegenüber Zulieferern, Carl Heymanns Verlag, Köln

Gemünden, H. G., Högl, M., Lechler, T. und Saad, A. (1999): Starting Conditions of Successful European R\&D-Consortia, in: K. Brockhoff, A. Chacrabarti und J. Hauschildt: The Dynamics of Innovation. Strategic and Managerial Implications, Springer, Berlin, 237-275

Gemünden, H. G. (1985): Perceived risk and information search. A systematic metaanalysis of the empirical evidence, in: International Journal of Research in Marketing, 2, 79-100

Granovetter, M. (1985):Economic Action and Social Structure: The Problem of Embeddedness, in: American Journal of Sociology, 91 (3), p. 481-510

Gruen, T. W. (2000): Membership Customers and Relationship Marketing, in: Sheth, J. N., Parvatiyar, A. (2000): Handbook of Relationship Marketing, Sage Publications, Thousand Oaks, 355-380 
Hahn, C. K., Watts, C. A., Kim, K. Y. (1990): The Supplier Development Program: A Conceptual Model, in: Journal of Purchasing and Materials Management, Spring, p. 2-7

Hahn, D., Kaufmann, L. (1999): Handbuch Industrielles Beschaffungsmanagement, Gabler, Wiesbaden

Hakansson, H., Gadde, L.-E. (1992): Supplier Relations, in: Ford, D. (2000): Understanding Business Markets, Thomson Learning, London, 400-429

Handfield, R. B., Ragatz, G. L., Petersen, K. J., Monczka, R. M. (1999): Involving Suppliers in New Product Development, in: California Management Review, 42 (1), p. $59-82$

Harland, C. M., Lamming, R. C., Cousins, P. D. (1999): Developing the concept of supply strategy, in: International Journal of Operations \& Production Management, 19(7), 650-673

Hartmann, H. (1992): Lieferantenbewertung - aber wie?, Deutscher Betriebswirte-Verlag, Gernsbach

Heege, F. (1987): Lieferantenportfolio, VWP Verlag, Nürnberg

Heide, J. B. (1994): Interorganizational Governance in Marketing Channels, in: Journal of Marketing, 58 (1), p. 71-85

Helfert, G. (1998): Teams im Relationship Marketing. Design effektiver Kundenbeziehungsteams, Gabler, Wiesbaden

Heydebreck, P. (1995): Technologische Verflechtung. Ein Instrument zum Erreichen von Produkt- und Prozessinnovationserfolg, Peter Lang, Frankfurt

Hildebrandt, H., Koppelmann, U. (2000): Beziehungsmanagement mit Lieferanten, Schäffer Poeschel, Stuttgart

Hofer, C. W., Schendel, D. (1978): Strategy Formulation: Analytical Concepts, West Publishing, St. Paul

Homburg, C. (1995): Single Sourcing, Double Sourcing, Multiple Sourcing...?, in: ZfB, 5 (8), p. 813-834

Hubmann, H. E., Barth, M. (1990): Das neue Strategiebewußtsein im Einkauf, in: Beschaffung aktuell, 10, p. 26-32

Hutzel, J. W: (1981): Große und kleine Zulieferer, Sprint, Tübingen

Joshi, A. W., Stump, R. L. (1999): Determinants of commitment and opportunism: Integrating and extending insights from transaction cost analysis and relational exchange theory, in: Revue Canadienne des Sciences de l'Administration, Vol. 16 (4), p. 334-352

Kalbfuß, W. (1998): Einkaufsstrategien, in: Strub, M.: Das große Handbuch Einkaufsund Beschaffungsmanagement, Verlag Moderne Industrie, Landsberg, p. 19-38

Kaplan, S., Sawhney, M. (2000): E-Hubs: The New B2B Marketplaces, in: Harvard Business Review, May/June, p. 97-103 
Kiedaisch, I. (1997): Internationale Kunden-Lieferanten-Beziehungen, Gabler, Wiesbaden

Koppelmann, U. (1997): Beschaffungsmarketing für die Praxis, Springer, Berlin

Kraljic, P. (1983): Purchasing must become supply management, in: Harvard Business Review, Sept-Oct, p. 109-117

Krapfel, R. E., Salmond, D., Spekman, R. (1991): A Strategic Approach to Managing Buyer-Seller Relationships, in: European Journal of Marketing, Vol. 25, No. 9, p 2237

Lamming, R. C., Caldwell, N., Harrison, D. (2000): Developing the concept and practice of transparency in inter-organizational relationships, North American Academy of Management Meeting, Toronto Ontario

Lamming, R. C., Cousins, P. D., Notman, D. M. (1996): Beyond vendor assessment, in: European Journal of Purchasing \& Supply Management, 2(4), 173-181

Littler, D., Leverick, F., Bruce, M. (1995): Factors Affecting the Process of Collaborative Product Development: A Study of UK Manufacturers of Information and Communications Technology Products, in. Journal of Product Innovation Management, 12 (1), p. 16-23

Markowitz, H. (1952): Portfolio Selection, in: Journal of Finance, Vol. 7

Matthyssens, P., Van den Bulte, C. (1994): Getting Closer and Nicer: Partnerships in the Supply Chain, in: Longe Range Planning, 27 (1), p. 72-83

Metcalf, L. E., Frear, C. R. (1993): The Role of Perceived Product Importance in Organizational Buyer-Seller Relationships, in: Journal of Business-to-Business Marketing, Vol. 1 (3), p. 63-85

Mittner, K. A. (1991): Differenzierte Lieferantenpolitik, in: Beschaffung aktuell, 4, p. 2123

Möller, K., Törrönen, P. (2000): Business Suppliers' Value Creation Potential: A Conceptual Analysis, $16^{\text {th }}$ IMP Conference, Bath

Monczka, R., Trent, R., Handfield, R. (1998): Purchasing and Supply Chain Management, South-Western College Publishing, Cincinnati

Morgan, R. M., Hunt, S. D. (1994): The Commitment-Trust Theory of Relationship Marketing, in: Journal of Marketing, 58 (7), p. 20-38

Müller, E. W. (1990): Gemeinsam Spitzenleistungen erreichen, in: Beschaffung aktuell, 4, p. $51-53$

Norris, D. G., McNeilly, K. M. (1995): The Impact of Environmental Uncertainty and Asset Specificity on the Degree of Buyer-Seller Commitment, in: Journal of Business-to-Business Marketing, Vol. 2(2), p. 59-85

Olsen, F., Ellram, L. M. (1997): A Portfolio Approach to Supplier Relationships, in: Industrial Marketing Management, 26 (2), p. 101-113

Piontek, J. (1997): Global Sourcing, Oldenbourgh Verlag, München 
Porter, M. E. (1996): Wettbewerbsvorteile, Campus, Frankfurt

Prahalad, Hamel (1995): Wettlauf um die Zukunft, Ueberreuter, Wien

Ritter, T. (1998): Innovationserfolg durch Netzwerkkompetenz, Gabler, Wiesbaden

Ryssel, R., Ritter, T., Gemünden, H. G. (2000): Trust, Commitment and Value-Creation in Inter-Organizational Customer-Supplier Relationships, $16^{\text {th }}$ IMP Conference, Bath

Saunders, M. (1997): Strategic Purchasing \& Supply Chain Management, $2^{\text {nd }}$ Edition, Prentice Hall, Essex

Shapiro, B. P., Rangan, V. K., Moriarty, R. T., Ross, E. B. (1987): Manage Customers for Profits, in: Harvard Business Review, September-October, 101-108

Smeltzer, L. R. (1997): The Meaning and Origin of Trust in Buyer-Supplier Relationships, in: International Journal of Purchasing and Materials Management, Winter, p. 40-48

Stoelzle, W. (2000): Beziehungsmanagement - Konzeptverständnis und Implikationen für die Beschaffung, in: Hildebrandt, H., Koppelmann, U.: Beziehungsmanagement mit Lieferanten, Schäffer Poeschel, Stuttgart, 1-24

Turnbull, P. W. (1983): A Review of Portfolio Planning Models for Industrial Marketing and Purchasing Management, in: European Journal of Marketing, 24 (3), p. 7-22

Turnbull, P. W., Zolkiewski, J. (1995): Profitability in Customer Portfolio Planning, $11^{\text {th }}$ IMP Conference, Manchester

Van Weele, A. J. (2000): Purchasing and Supply Chain Management, $2^{\text {nd }}$ edition, Business Press, Padstow

Venkatesan, R. (1992): Strategic Sourcing: To Make or Not to Make, in: Harvard Business Review, Nov.-Dec., p. 98-107

Von Hippel, E. (1988): The Sources of Innovation, Oxford University Press, New York

Walter, A. (1998): Der Beziehungspromotor. Ein personaler Gestaltungsansatz für erfolgreiches Relationship Marketing, Gabler, Wiesbaden

Walter, A., Müller, T. A., Helfert, G. (2000): The Impact of Satisfaction, Trust, and Relationship Value on Commitment: Theoretical Considerations and Empirical Results, $16^{\text {th }}$ IMP Conference, Bath

Walter, A., Ritter, T., Gemünden, H.-G. (2000): Value-Creation in Buyer-SellerRelationships: Theoretical Considerations and Empirical Results from a Supplier's Perspective, accepted for publication in Industrial Marketing Management

Walter, A., Ritter, Th., Gemünden, H. G. (1999): Value Creating Functions of Customer Relationships from a Supplier's Perspective: Theoretical Considerations and Empirical Results, $15^{\text {th }}$ IMP Conference, Dublin

Wertz, B. (2000): Management von Lieferanten-Produzenten-Beziehungen, Gabler, Wiesbaden 
Wildemann, H. (1999): Das Konzept der Einkaufspotentialanalyse, in: Hahn, D., Kaufmann, L.: Handbuch Industrielles Beschaffungsmanagement, Gabler, Wiesbaden, p. 435-452

Wilson, D. T. (1995): An Integrated Model of Buyer-Seller Relationships, in: Journal of the Academy of Marketing Science, 23 (4), 335-345

Wilson, D. T., Jantrania, S. (1996): Understanding the Value of a Relationship, in: AsiaAusralia Marketing Journal, 2 (1), 55-66

Wind, Y., Douglas, S. (1981): International Portfolio \& Strategy - The Challenge of the 80s, in: Journal of International Business Studies, Fall

Witt, F.-J. (1986): Beschaffungs-Portfolios als strategisches Instrument, in: Beschaffung aktuell, 11, p. 33-35

Wolters, H. (1996): Auswirkungen der Systembeschaffung für die Customer Integration aus Sicht von Zulieferunternehmen der Automobilindustrie, in: Kleinaltenkamp, M., Fließ, S., Jacob, F.: Customer Integration. Von der Kundenorientierung zur Kundenintegration, Gabler, Wiesbaden, p. 233-244 